\title{
The Critical Role of the Construction Industry in Achieving the Sustainable Development Goals (SDGs): Delivering Projects for the Common Good
}

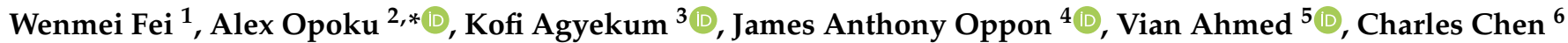 \\ and Ka Leung Lok ${ }^{7}$
}

check for updates

Citation: Fei, W.; Opoku, A.; Agyekum, K.; Oppon, J.A.; Ahmed, V.; Chen, C.; Lok, K.L. The Critical Role of the Construction Industry in Achieving the Sustainable Development Goals (SDGs): Delivering Projects for the Common Good. Sustainability 2021, 13, 9112. https://doi.org/10.3390/su13169112

Academic Editor: Marija Bogataj

Received: 10 July 2021

Accepted: 11 August 2021

Published: 14 August 2021

Publisher's Note: MDPI stays neutral with regard to jurisdictional claims in published maps and institutional affiliations.

Copyright: (c) 2021 by the authors. Licensee MDPI, Basel, Switzerland. This article is an open access article distributed under the terms and conditions of the Creative Commons Attribution (CC BY) license (https:/ / creativecommons.org/licenses/by/ $4.0 /)$.
1 Faculty of Real Estate Marketing, Chongqing College of Architecture and Technology, Chongqing 401331, China; 2017025@ctbu.edu.cn

2 UCL Bartlett School of Sustainable Construction, University College London, London WC1E 7HB, UK

3 Department of Construction Technology and Management, Faculty of Built Environment, College of Art and Built Environment, Kwame Nkrumah University of Science and Technology, Kumasi AK 384, Ghana; kagyekum.cap@knust.edu.gh

4 Department of Building Technology, School of Built and Natural Environment, Cape Coast Technical University, Cape Coast CC 156, Ghana; james.oppon@cctu.edu.gh

5 College of Engineering, American University of Sharjah, Sharjah P.O. Box 26666, United Arab Emirates; vahmed@aus.edu

6 College of Business and Information Technology, University of Phoenix, Honolulu, HI 96813, USA; kalebiz@email.phoenix.edu

7 National Research Base of Intelligent Manufacturing Service, Chongqing Technology and Business University, Chongqing 400067, China; k.1.lok@edu.salford.ac.uk

* Correspondence: alex.opoku@ucl.ac.uk

Abstract: In 2015, the United Nations (UN) adopted the 2030 agenda for Sustainable Development, which set out 17 Sustainable Development Goals (SDGs), 169 targets and 231 unique indicators as a significant initiative towards socio-economic development. The SDGs provide the construction industry with a new lens through which global needs and desires can be translated into business solutions. This paper explores the role of the construction industry in achieving the 2030 Sustainable Development Goals. The paper uses an explanatory sequential design with an initial quantitative instrument phase, followed by a qualitative data collection phase. Following a comparative review of the literature on the 17 SDGs, a questionnaire was designed and administered among 130 respondents, and 105 responses were received. These data were then validated through semi-structured interviews with 16 sustainable construction experts. Data obtained from the semi-structured validation interviews were analysed through side-by-side comparisons of the qualitative data with the quantitative data. The findings show that the construction industry has a critical role in achieving almost all the 17 SDGs. The roles were, however, prevalent in 10 key SDGs, namely: sustainable cities and communities (SDG 11); climate action (SDG 13); clean water and sanitation (SDG 6); responsible consumption and production (SDG 12); industry, innovation and infrastructure (SDG 9); life on land (biodiversity) (SDG 15); gender equality (SDG 5); good health and well-being (SDG 3); affordable and clean energy (SDG 7); decent work and economic growth (SDG 8). The study confirmed the role played by the construction industry in achieving these SDGs. The findings from this study provide further insights into the ever-increasing state-of-the-art regarding the construction industry's role in achieving Sustainable Development Goals.

Keywords: construction industry; sustainable business; sustainable development; SDG2030; Sustainable Development Goals (SDGs)

\section{Introduction}

All the 193 UN member states adopted the Sustainable Development Goals (SDGs) in September 2015 to address the global development challenges to end poverty, protect the 
planet and ensure prosperity for all [1]. The Sustainable Development Goals, which are also called the Global Goals, apply to both developed and developing countries even though various countries have different challenges [2]. The 17 universal goals are supported by 169 targets and measured by 231 unique indicators, as indicated in Table 1 . The SDGs cover 15 years ending in 2030 and replaces the Millennium Development Goals (MDGs) that covered eight goals and twenty-one targets from 2000 to 2015. While the MDGs were mainly aimed at governments in developing countries, the SDGs are global and aim at governments, businesses and non-governmental organisations in developing and developed countries [3].

Table 1. The Sustainable Development Goals (SDGs), targets and indicators.

\begin{tabular}{|c|c|c|c|}
\hline Goals & Description & Nr. of Targets & Nr. of Indicators \\
\hline Amintin Goal 1 & No poverty: end poverty in all its forms everywhere & 7 & 13 \\
\hline SIII Goal 2 & $\begin{array}{l}\text { Zero hunger: end hunger, achieve food security and improved nutrition, and promote } \\
\text { sustainable agriculture }\end{array}$ & 8 & 14 \\
\hline$-y^{\circ}$ Goal 3 & Good health and well-being: ensure healthy lives and promote well-being for all ages & 13 & 28 \\
\hline 4 i & $\begin{array}{l}\text { Quality education: ensure inclusive and equitable quality education and promote } \\
\text { life-long learning opportunities for all }\end{array}$ & 10 & 12 \\
\hline Goal 5 & Gender equality: achieve gender equality and empower all women and girls & 9 & 14 \\
\hline 6 & $\begin{array}{c}\text { Clean water and sanitation: ensure availability and sustainable management of water } \\
\text { and sanitation for all }\end{array}$ & 8 & 11 \\
\hline Goal 7 & $\begin{array}{l}\text { Affordable and clean energy: ensure access to affordable, reliable, sustainable and } \\
\text { modern energy for all }\end{array}$ & 5 & 6 \\
\hline 行 & $\begin{array}{l}\text { Decent work and economic growth: promote sustained, inclusive and sustainable } \\
\text { economic growth, full and productive employment, and decent work for all }\end{array}$ & 12 & 16 \\
\hline 4 Goal 9 & $\begin{array}{l}\text { Industry, innovation and infrastructure: build resilient infrastructure, promote } \\
\text { inclusive and sustainable industrialisation, and foster innovation }\end{array}$ & 8 & 12 \\
\hline 10 스를 & Reduced inequalities: reduce inequality within and among countries & 10 & 14 \\
\hline A & $\begin{array}{l}\text { Sustainable cities and communities: make cities and human settlements inclusive, } \\
\text { safe, resilient and sustainable }\end{array}$ & 10 & 14 \\
\hline Goal 12 & $\begin{array}{l}\text { Responsible consumption and production: ensure sustainable consumption and } \\
\text { production patterns }\end{array}$ & 11 & 13 \\
\hline Goal 13 & Climate action: take urgent action to combat climate change and its impacts & 5 & 8 \\
\hline$\stackrel{14}{\sim}$ Goal 14 & $\begin{array}{l}\text { Life below water (oceans): conserve and sustainably use the oceans, seas and marine } \\
\text { resources for sustainable development }\end{array}$ & 10 & 10 \\
\hline$\stackrel{15}{=}$ Goal 15 & $\begin{array}{l}\text { Life on land (biodiversity): protect, restore and promote sustainable use of terrestrial } \\
\text { ecosystems, sustainably manage forests, combat desertification, halt and reverse land } \\
\text { degradation, and halt biodiversity loss }\end{array}$ & 12 & 14 \\
\hline Goal 16 & $\begin{array}{c}\text { Peace, justice and strong institution: promote peaceful and inclusive societies for } \\
\text { sustainable development, provide access to justice for all and build effective, } \\
\text { accountable and inclusive institutions at all levels }\end{array}$ & 12 & 24 \\
\hline 89 Goal 17 & $\begin{array}{l}\text { Partnership for the goals: strengthen the means of implementation and revitalise the } \\
\text { global partnership for sustainable development. }\end{array}$ & 19 & 24 \\
\hline- & - & 169 & $247 *$ \\
\hline
\end{tabular}

* The total number of indicators listed in the global indicator framework of SDG indicators is 247; however, twelve indicators repeat under two or three different targets resulting in 231 unique indicators. Adapted from [1]. 
The SDGs are guided by the principle of universality, which means that all countries and citizens have a role to play towards their achievement. The global goals provide an opportunity for all nations to protect the environment, eradicate poverty, combat the effects of climate change, reduce inequalities in society and improve human well-being [4]. To successfully achieve the SDGs by 2030, all sectors of society and all government levels should integrate the goals in the local planning process. Local government actions that capture the SDGs' inclusiveness, universality and equity spirit are essential in leaving no one behind. Localization of the SDGs will involve local governments and relevant stakeholders adapting, implementing and monitoring the local level's SDG targets. Adams [5] believes that the SDGs' realisation will be challenging without collaboration between governments, the private and public sector, and civil society organisations. The universal set of goals, targets and indicators of the 2030 SDGs require businesses, governments and civil society [3]. The realisation of the 17 Sustainable Development Goals requires contribution from business organisations in managerial and organisational reporting due to the interlinked nature of the SDGs [6].

The principle of "Leaving No One Behind" underpinning the SDGs means that progress towards achieving the goals should be measured concerning how well the poorest individuals and groups in society are improving in their socio-economic development. The principle will ensure that development is equally distributed across all nations and demographic groups [3]. The SDGs are transformational and aim to develop sustainable, inclusive and sustained economic growth across the world. The 17 goals can be grouped into the five "P areas" of people, planet, prosperity, peace and partnership as illustrated in Figure 1. It is argued that the five Ps of the SDGs (people, planet, prosperity, peace and partnerships) require different stakeholders, such as governments, institutions and businesses. The construction industry is also a key stakeholder; hence, it is important that the industry develops approaches to align its business strategies with the SDGs. Since the introduction and adoption of the 2030 agenda, scholars and practitioners within various sectors have been trying their best to study the possible implementation strategies of the SDGs. Other researchers have also tried to map various methods to understand the relations and contradictions within the agenda as a means of proposing methods to prioritize actions to achieve the SDGs. Despite these developments, little is known about the role of the construction industry in achieving the SDGs. As a potential stakeholder in the business world, it is only prudent that such a study is undertaken to bring out the construction industry's critical role in the implementation of the SDGs. This potential gap has, therefore, made it necessary to undertake this study which aims at exploring the critical role of the construction industry in achieving the 2030 Sustainable Development Goals.

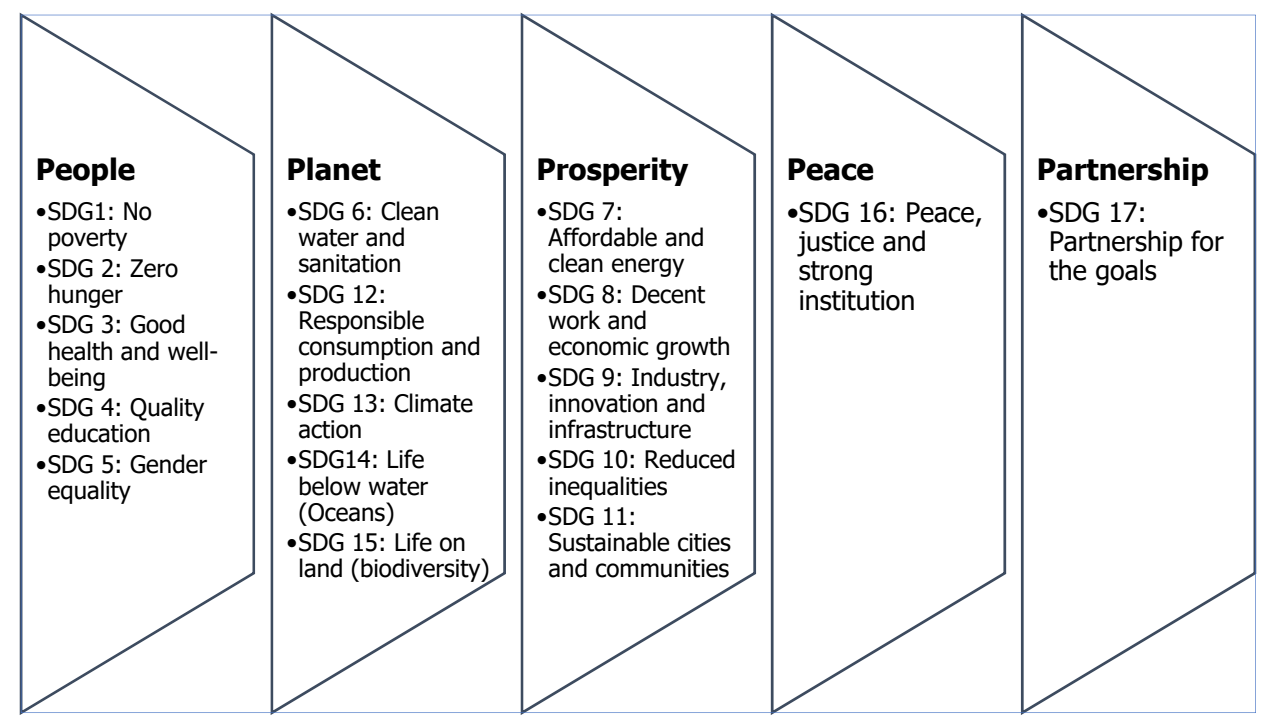

Figure 1. The five "P Areas" of the Sustainable Development Goals. 
The paper is divided into five main sections with this section introducing readers to the theme under investigation. The next section of the paper presents a literature review, followed by a discussion of the adopted research methodology. The fourth section presents data collection, analysis and discussion, and the final section concludes the research.

\section{Literature Review}

\subsection{The Sustainable Development Goals Framework}

Even though sustainable development may have been defined differently by different sectors and organisations, the concept should be integrated across other sectors and fields. Sustainable development aims to reduce the negative impacts of human activities on the environment while ensuring socio-economic development. To achieve a sustainable society, sustainable development should be seen as a process and not an end-state and should be used as the new lens for addressing global challenges [7]. According to Sachs et al. [8], the SDGs can be achieved through six major societal transformations, including: (1) education and skills, (2) health and well-being, (3) clean energy and industry, (4) sustainable land use, (5) sustainable cities and (6) digital technologies. The six transformations guided by two key principles of "leaving no one behind" and "ensuring circularity and decoupling" aim to provide government ministries, international community businesses and civil society tangible strategies towards the realisation of the SDGs. Even though the SDGs combine the environmental, social and economic developmental issues, Dickens et al. [9] questioned if the 231 unique SDG indicators are fit for purpose in the fight towards sustainable development. According to Hopwood et al. [10], sustainable development is humancentred. The transformational view of sustainable development allows trade-offs between environmental and social dimensions with a strong commitment to social issues such as access to good health. Society depends on the environment, while the economy depends on society.

The SDGs are not independent of each other even though they are formulated as individual goals; they are interlinked and intertwined in a unified framework offering the opportunity for nations and businesses to formulate strategic policy interventions and solutions that addresses multiple goals simultaneously [11,12]. Due to the integrated nature of the Sustainable Development Goals and their targets, any progress towards one goal/target is also linked through multifaceted feedbacks to other goals/targets, and any interactions and trade-offs between them could produce bad outcomes if policies and actions are not pre-designed properly $[13,14]$. According to a study by the University of Cambridge Institute for Sustainability Leadership (CISL) [15], the SDGs are deeply interconnected, and none can be delivered in isolation. It adds that the built environment, planning, architecture and design interact with every goal.

Nations and organisations adopting the SDGs should identify the strong and positive linkages between targets and indicators and allow the prioritization and the allocation of scarce resources to leverage efficiency with policies and programmes targeting the goals with the greatest potential to impact positively and produce sustainable development outcomes [16]. Accordingly, United Nations Statistical Commission argues that defining and identifying linkages between the SDGs is complex because their interactions can be examined and interpreted in a variety of ways: across the three dimensions of sustainable development (economic, social and environmental); across the five thematic areas of the SDGs (people, planet, prosperity, peace and partnerships) [16]. Kroll et al. [17], confirmed the synergies and trade-offs within and across the SDGs. For example, SDG 1 (no poverty) is interlinked with many goals, while SDG 12 (responsible consumption and production) relates to trade-offs regarding economic progress goals. The International Council for Science's [18] study on the nature and type of interlinkages across the SDGs revealed that the SDGs could influence each other positively or negatively. For example, there is a positive interaction between SDG 13 and SDGs 6, 7, 9, 11 and 16 [17].

According to Nilsson et al. [12], the SDGs form an "indivisible whole", meaning that the goals and targets relate to and depend on each other [12,19]. For example, SDG 3 (good 
health and well-being) cannot be achieved in isolation unless SDG 2 (zero hunger) has been achieved, and both goals are interlinked with SDG 10 (reduced inequalities) and SDG 8 (decent work and economic growth). However, SDG 4 (quality education) has strong positive links with SDG 3 (health and well-being), SDG 5 (gender equality), SDG 8 (decent work and economic growth) and SDG 1 (poverty reduction). On the other hand, SDG 1 (zero poverty), SDG 5 (gender equality) and SDG 6 (clean water) are all linked with 13 other goals. Again SDG 11 (sustainable cities and communities) is critical for the sustainable development of the planet and has a link with all the other 16 goals, while SDG 4 (quality education) is linked with 14 goals [16]. Figure 2 illustrates the interlinked and intertwined nature of the Sustainable Development Goals.

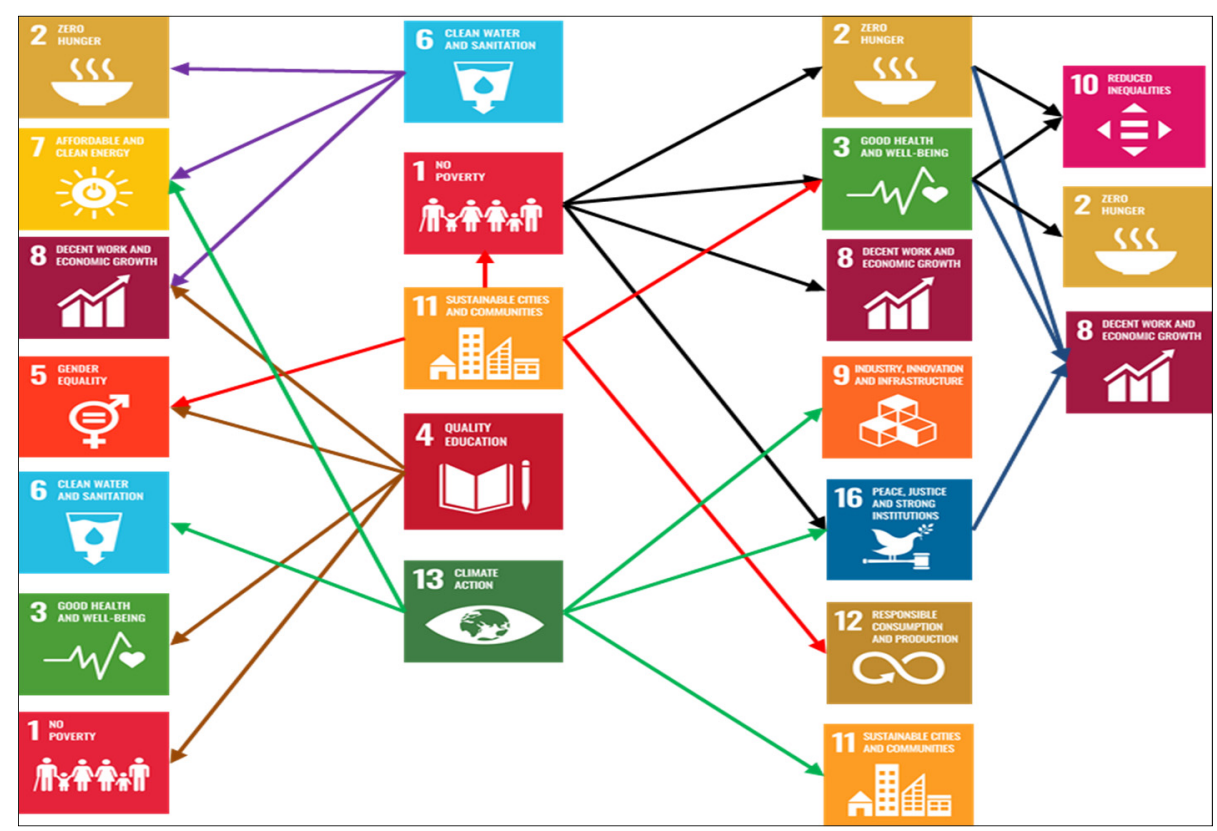

Figure 2. The interlinked nature of the SDGs.

\subsection{The Built Environment and the SDGs}

The built environment is a hub of economic activities, individuals and families, and society's cultural heritage. The built environment protects life and health, its inhabitants' psychological and social welfare, and sustains aesthetic and cultural values [20,21]. However, it consumes lots of energy and resources while generating a large amount of waste. It is estimated that greenhouse gas emissions will rise to about $37 \%$ in 2030 compared to 2005 levels, affecting the natural and the built environment if efficient policies are not implemented [22]. The solution to this challenge is the design and construction of improved built asset supported by appropriate management tools and regulatory frameworks that address sustainable development issues [23]. The conservation of historic cities is an effective strategy in reducing $\mathrm{CO}_{2}$ emissions when compared to their replacement by new buildings. New construction projects have more damaging impacts in the short to mid-term; however, conserving an existing building saves original energy and $\mathrm{CO}_{2}$ investment [21,24]. The connections between components of the built environment, such as individual buildings, transport systems, urban landscapes and other infrastructure, should reduce environmental impacts in terms of energy, carbon, waste or water. Sustainable regeneration projects can also significantly contribute to social well-being [25]; achieving a sustainable built environment will impact the society's ability to realise the SDGs. With more than half of humanity living in cities and the number of urban residents growing by nearly 73 million every year, it is estimated that urban areas account for $70 \%$ of the world's gross domestic product. The construction industry can play a crucial role in achieving SDG 11 [26,27]. Goal 11 highlights the central role of urbanisation in sustainable development, describing the 
need for inclusive, safe, resilient, and sustainable cities and communities through relevant public policy [3].

A recent $\mathrm{UN}$ report estimates that about 3 billion people live in urban slum conditions due to the problem of urbanisation and population growth and would require adequate and affordable housing by 2030. The pace of constructing new affordable housing is slow compared with the global population growth, requiring countries to develop and implement national urban plans to address this challenge [28]. Urbanisation should be at the heart of the 2030 sustainable development agenda. Teferi and Newman [29] believe that regenerating the urban slums in the developing world could significantly contribute to the realisation of many of the SDGs, including SDG 1 (end poverty), SDG 6 (clean water and sanitation), SDG 7 (affordable and clean energy) and SDG 11 (sustainable cities and communities). The paradigm shift towards a low-carbon society cannot be achieved without a sustainable and efficient infrastructure that can withstand climate change. Maintaining sustainable and resilient infrastructure systems that can withstand floods, keep road systems, and the reliability of building structures is crucial for guaranteeing essential services such as energy and water supplies [30]. The built environment has a long-term impact on the quality of life, prosperity, health, well-being and happiness of people and communities regarding the planning, design, management and maintenance of the built asset (House of Lords [31] as cited in Opoku [32]). The built environment needs to be flexible and adaptable to future uses and be resilient to climate change. The built environment should lead the fight against climate change towards low-carbon and a sustainable future. The U.K. Government's 2025 construction strategy target of reducing carbon emissions by $50 \%$ based on the 2 degrees Celsius target temperature increase need to be reconsidered if the construction sector can contribute significantly to the 1.5 degrees Celsius target by 2030 [33]. A sustainable built environment designed with energy-efficient infrastructure can contribute meaningfully to reducing the energy demand and eventually reducing climate change. Retrofitting existing infrastructure can also increase urban resilience to disaster and ensure sustainable cities and communities (SDG 11) [34].

\subsection{The Construction Industry and the SDGs}

The Sustainable Development Goals offer the construction industry a new opportunity to expand its focus away from the environmental dimension of sustainability [35]. Construction project delivery and its management could be recognised as sustainable if social, economic and environmental considerations are integrated into the project delivery processes, standards and practices [36]. Even though the construction industry has enormous social, economic and environmental impacts during the design and building process, it can play a critical role towards the achievement of the SDGs as the industry builds tomorrow's world [37,38]. For example, construction and demolition activities generate large volumes of waste. This requires adopting practices that will reduce waste generated and maximise re-use to improve efficient resource use and reduce the negative impact on the environment [39]. However, Mahpour [40] argues that the circular economy is a sustainable concept that could be adopted to exploit resources and manage construction and demolition waste efficiently.

The industry is a key partner in the global effort towards realising sustainable development by 2030 through the delivery of sustainable projects. According to Ofori [41], the 17 SDGs have been classified from the perspective of construction into (a) basic human and national needs-goals 1, 2, 3, 4, 5 and 8; (b) what construction must-do-goals 9-11; (c) some of the construction's results-goals 6-7; (d) inputs and methods of the construction industry-goals 12,13, 14 and 15. Through land development, resource use, waste generation and labour practices, the construction industry impacts the achievement of the SDGs throughout its life cycle [42]. While the construction industry offers economic growth and employment opportunities, the industry is tainted with poor practices such as modern slavery affecting human and labour rights. These are linked with the realisation of SDGs 
$1,8,10$ and 16 [42]. Interestingly, corrupt practices in the construction industry through planning, procurement and payments affect SDG 16 socially, politically and economically.

According to BDG [37], the construction and property sector connect with every one of the 17 SDGs; however, Opoku [32] argues that the construction industry can highly impact the realisation of several SDGs, including SDG2 (zero hunger), SDG 3 (good health and well-being), SDG4 (quality education), SDG6 (clean water and sanitation), SDG7 (affordable and clean energy), SDG8 (decent work and economic growth), SDG 9 (industry, innovation and infrastructure), SDG10 (reduced inequalities), SDG11 (sustainable cities and communities) and SDG13 (climate action). Sustainable development has been described as the new project management paradigm [43]. The SDGs should be embedded into the early project goal setting, business case, project benefits and success criteria, specification, and project outcomes design. During the planning, design and construction stage, the practices and materials used are significant causes of greenhouse gas emissions and these impact the SDGs.

Gareis et al. [44] believe that integrating sustainability principles into project management could improve the overall project delivery by reducing the likelihood of project cancellation/interruption, managing the project complexity, and creating economic benefits and social value. In particular, the construction industry has a vital role in preserving biodiversity (SDG 15), but this is usually not a priority area for the industry. Therefore, the construction industry can lead the agenda towards the integration of biodiversity at the heart of sustainable development [45]. Biodiversity should be incorporated into the built environment by providing green urban spaces, such as green roofs, that can contribute to urban biodiversity conservation [46]. New development construction projects should integrate biodiversity schemes such as creating habitats for wildlife by providing nest boxes, living roofs and landscapes. These schemes should not add high cost to the overall construction project budget. Integrating biodiversity into the planning, management and legislation process of our cities and key infrastructure is essential for promoting biodiversity (SIDA [47] as cited in Opoku [45]). A study by Omer and Noguchi [48] revealed that building materials used in construction projects can directly affect the achievement of the SDGs, particularly SDG 3, SDG 7, SDG 9, SDG 11, SDG 12, SDG 13 and SDG 15 and indirectly impact SDG 2, SDG 5, SDG 10 and SDG 16. It highlights that building materials used in the construction industry considerably impact 13 goals and 25 targets of the Sustainable Development Goals. The construction industry negatively impacts the environment through its activities such as waste from project sites, loss of biodiversity and building materials use [49]. The construction companies should conserve and preserve biodiversity, which is crucial for realising the SDGs during the delivery of construction projects [45]. Construction and demolition waste is a critical issue for the construction industry since the industry generates a large quantity of such waste even though most of it could be recycled. They argue that construction and demolition waste reduction strategies should start from the early project design stage, through construction and the building operation stage [50,51]. The ability of construction organisations to cope with the journey towards sustainable change requires organisational learning. Construction organisations must engage in organisational learning methods that embrace sustainable innovation.

\section{Research Methodology}

The paper adopted a mixed-method approach [52]. Kroll and Neri [53] proposed six types of mixed-method designs: sequential exploratory, sequential explanatory, sequential transformative, concurrent nested, concurrent transformative and concurrent. Wisdom and Creswell [54] also proposed five primary mixed-method approaches to be adopted depending on the research question to be addressed. These approaches are listed to include validating findings using quantitative and qualitative data sources, using qualitative data to explore quantitative results, developing survey instruments, using qualitative data to augment a quantitative outcome of a study, and involving community-based stakeholders [54]. Following these propositions, this paper adopted the sequential explanatory design, which 
collects quantitative data and validates it with qualitative data. The methodology (showing the various procedures) adopted for this study is summarised in the flowchart (Figure 3). The explanation to the flowchart is also provided in Sections 3.1 and 3.2.

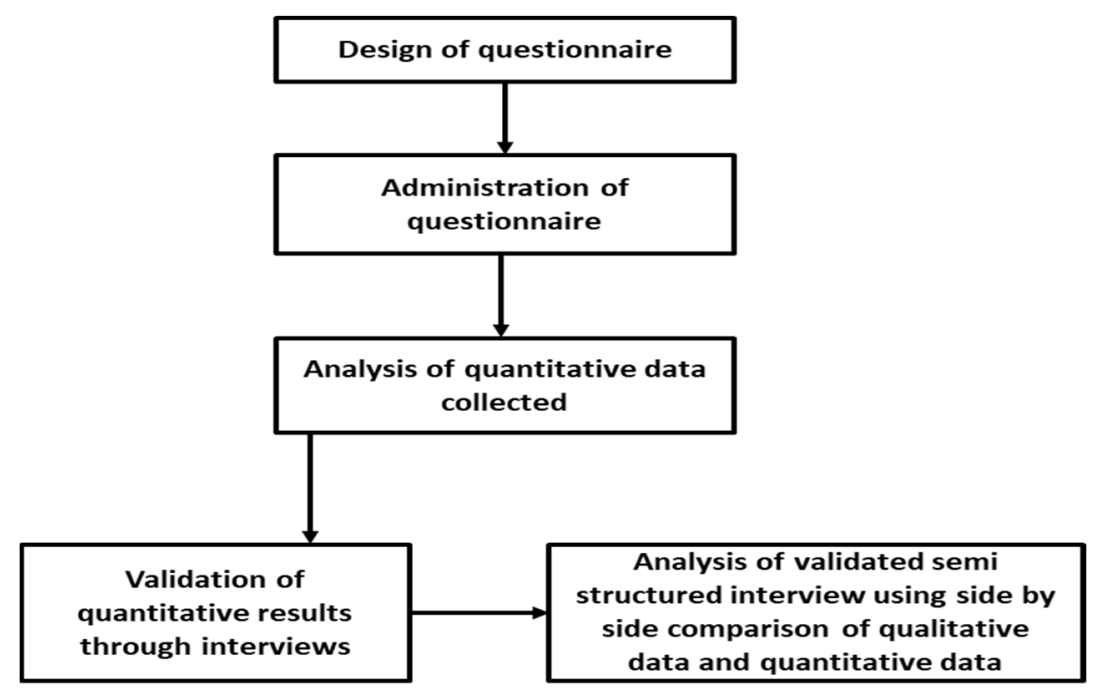

Figure 3. Flow chart indicating methodology procedure.

\subsection{Survey Design, Administration and Analysis}

Following a comparative review of related literature, a questionnaire was prepared to collect the quantitative data. The questionnaire was divided into two sections. The first section sought information on respondents' demographic background, while the second part solicited the views of respondents regarding the role of the construction industry on the realisation of the SDGs. In the first section, respondents' background information (i.e., work experience, position at work and education level) was gathered. In the second section, respondents were asked to rank on the Likert scale of 1 to 5 (where 1 = highly disagree, 2 = disagree, $3=$ neither agree nor disagree, $4=$ agree, $5=$ highly agree) their level of agreement with the roles the industry plays in achieving the 17 Sustainable Development Goals. The five-point Likert scale was used for this study because it has been extensively used in studies of similar nature and, furthermore, results are easy to interpret [55]. Before administering the questionnaire, it was piloted among 10 professionals with diverse backgrounds in the built environment and experience in the Sustainable Development Goals and the construction industry. The piloting was necessary to ensure the comprehensibility and suitability of the questionnaire for the intended purpose.

The respondents were, therefore, selected from a range of construction industry professionals and academics. Two non-probability sampling approaches (purposive and snowball sampling approaches) were used to sample respondents for this study. The targeted sample was purposively selected from the authors' networks of academics and construction industry professionals with knowledge and experience in sustainable construction. A web-based questionnaire with a link to the survey was made available and sent to an initial identifiable respondent. The purposive sampling approach helped in the identification of these respondents. Purposive sampling allows for the selection of respondents with special characteristics [56]. Through the snowball sampling technique, the initial identifiable respondents were required to subsequently refer the questionnaire to other potential respondents. Rowley [57] recommends using a non-probability sampling approach where there is a non-availability of professionals' databases with in-depth knowledge regarding certain areas.

The survey data were coded into SPSS version 22 and analysed based on the questionnaire's two distinct sections. Data from the first section that sought the demographic background of the respondents were analysed using percentages. Data from the second section were analysed via inferential statistics. A four-level data analysis framework used 
in a related study [58] was adopted for this section. The four-level data analysis framework comprised: (1) determining the reliability of the data for further analysis using the Cronbach's alpha coefficient test; (2) determining the relative impact and ranking the Sustainable Development Goals based on the impact of the construction industry; (3) testing the significance of the mean values of the agreement or disagreement with the impact on the SDGs using the one-sample $t$-test; (4) calculating Kendall's W to test the general agreement among the different professional groups (i.e., the academics and industry professionals).

Out of a total of 130 questionnaires distributed via email to respondents, 105 were returned, indicating a good response rate of $81 \%$. One of the problems that could be encountered in this way of obtaining responses could be the potential of sending emails to people of the same company. To counteract this problem, the respondents were contacted by telephone to obtain personal emails before sending the surveys out, and follow-up reminder emails were sent two weeks after the initial distribution. A breakdown of the 105 returned questionnaires shows that 22\% were Surveyors, 20\% were Civil Engineers, Academicians constituted 17\%, Project Managers made up 13\%, Architects made up 15\%, while Construction Engineers were 13\%. The majority of the respondents representing 75\% had working experience from 11 to 21 years and above, while $25 \%$ were in the region of 0 to 10 years. For their educational background, the majority representing $41 \%$ had a master's degree, 29 had a bachelor's degree, 19\% were PhD holders and 11\% had other certificates.

\subsection{Design of Qualitative Interview Protocol, Conducting Interviews and Analysis of Qualitative Data}

The qualitative phase of the study was initiated based on the results from the quantitative phase. This phase was necessary to obtain interviewees to explain the quantitative results in more detail through the qualitative data. An interview guide was prepared, which required the interviewees to provide information on how the construction industry can help realise the key SDGs identified in the quantitative study. This study's qualitative aspect further captures the experiences and perceptions of research participants through words and images and interprets meanings and explanations to develop an understanding of the quantitative data collected [59,60]. Opoku [32] describes sustainable development as people-centred and, therefore, argue that the adoption of a qualitative data collection method to augment the quantitative data for such study is the most appropriate to capture relevant data and information to understand social reality from the perspective of the research participants. An in-depth semi-structured interview is used for data collection to explore the construction industry's role towards the realisations of the 2030 Sustainable Development Goals. The interview involved 16 experts purposefully selected from industry and academia; the participants were selected based on their expertise in the Sustainable Development Goals.

According to Morse [61], a minimum of six interviews is good for a qualitative study. However, Guest [62] believes that 12 interviews are sufficient for a qualitative study as a saturation point is reached beyond this number. The interviewees included seven industry professionals and nine academics with experience and expertise in the SDGs and the construction industry. Approximately 20 experts were contacted to participate in this phase of the research, and 16 finally agreed to participate in the research. The collected interview data were analysed through content analysis and comparison of qualitative data with quantitative data under the relevant themes to obtain a better understanding. A profile of the interviewees is presented in Table 2. 
Table 2. A profile of the interviewees.

\begin{tabular}{|c|c|c|c|c|}
\hline \multirow{2}{*}{ Interviewees } & \multirow{2}{*}{ Job Title } & \multicolumn{2}{|c|}{ Interviewee's Background } & \multirow{2}{*}{ Years of Experience } \\
\hline & & Academic & Practitioner & \\
\hline A & Senior Lecturer & $\sqrt{ }$ & - & 26 \\
\hline $\mathrm{B}$ & Lecturer & $\sqrt{ }$ & - & 16 \\
\hline $\mathrm{C}$ & Sustainability RD Manager & - & $\sqrt{ }$ & 10 \\
\hline $\mathrm{D}$ & Senior Lecturer & $\sqrt{ }$ & - & 15 \\
\hline $\mathrm{E}$ & Professor and Managing Director & $\sqrt{ }$ & - & 25 \\
\hline $\mathrm{F}$ & Project Director & - & $\sqrt{ }$ & 30 \\
\hline G & Researcher & $\sqrt{ }$ & - & 5 \\
\hline $\mathrm{H}$ & Service Performance Analyst & - & $\sqrt{ }$ & 6 \\
\hline $\mathrm{I}$ & Lecturer & $\sqrt{ }$ & - & 7 \\
\hline $\mathrm{J}$ & Project Surveyor & - & $\sqrt{ }$ & 5 \\
\hline K & Professor of Construction Project Management & $\sqrt{ }$ & - & 35 \\
\hline $\mathrm{L}$ & Senior Lecturer & $\sqrt{ }$ & - & 15 \\
\hline M & Director & - & $\sqrt{ }$ & 7 \\
\hline $\mathrm{N}$ & Architectural Technician & - & $\sqrt{ }$ & 4 \\
\hline $\mathrm{O}$ & Senior Lecturer & $\sqrt{ }$ & - & 18 \\
\hline $\mathrm{P}$ & Sustainability Director & - & $\sqrt{ }$ & 12 \\
\hline
\end{tabular}

\section{Results and Discussion}

This section presents and discusses the results obtained from the quantitative and qualitative data. The quantitative bits of the results are first presented, after which the SDGs critically impacted are identified. The top 10 SDGs where the construction industry can highly impact its realisation are then discussed with support from the qualitative views/opinions of the interviewees.

\subsection{Assessing the Impact the Construction Industry Has on Various SDGs}

This paper explores the role of the construction industry towards the realisation of the Sustainable Development Goals. To achieve this specific objective, respondents level of agreement with the impact of the construction industry on the various SDGs was evaluated using a five-point Likert scale; hence, there was the need to determine the data's reliability. This was achieved by using Cronbach's alpha coefficient to measure the internal consistency of the data obtained. The Cronbach's alpha coefficient increases from 0 to 1 , with 1 indicating the maximum level of validity and reliability of the data [63]. However, a Cronbach's alpha value above the threshold of 0.7 is highly reliable [64]. For all the 17 SDGs, the Cronbach's alpha coefficient was 0.735 ; hence, the data are regarded as highly reliable.

After the reliability assessment, descriptive means and one-sample $t$-tests were used to further analyse the respondents' level of agreement with the 17 SDGs as impacted by the construction industry. The one-sample $t$-test was used to test the mean values of the level of respondents' agreement with the various SDGs at a confidence level of $95 \%$, a $p$ value of 0.05 , and against a test value of 3.5. The results as obtained are shown in Table 3 .

From Table 3 , the mean values of 10 out of the 17 SDGs were statistically greater than the test value of 3.5. Table 3 further depicts that the $p$ values obtained for all the various factors are less than 0.05 . These results imply that the respondents agreed that 10 out of the 17 SDGs were impacted by the construction industry (see Tables 3 and 4). The respondents belonged to different professions (i.e., academics and industry practitioners); hence, there was a need to check whether they agreed on ranking the 10 SDGs (Table 4). To achieve this, the value of Kendall's W was determined (Table 4). 
Table 3. Summary analysis of all the SDGs.

\begin{tabular}{|c|c|c|c|c|c|}
\hline & & & & Test Value 3.5 & \\
\hline Code & Goal Description & Mean & Std. Deviation & Sig. Two-Tailed & Ranking \\
\hline SDG 1 & No poverty & 2.92 & 1.166 & 0.000 & 13 \\
\hline SDG 2 & Zero hunger & 2.80 & 1.228 & 0.000 & 17 \\
\hline SDG 15 & Life on land (biodiversity) & 4.32 & 0.814 & 0.000 & 7 \\
\hline SDG 4 & Quality education & 3.62 & 0.641 & 0.060 & 11 \\
\hline SDG 5 & Gender equality & 3.70 & 0.950 & 0.029 & 10 \\
\hline SDG 11 & Sustainable cities and communities & 4.67 & 0.583 & 0.000 & 1 \\
\hline SDG 3 & Good health and well-being & 3.79 & 0.817 & 0.000 & 9 \\
\hline SDG 9 & Industry, innovation and infrastructure & 4.52 & 0.622 & 0.000 & 5 \\
\hline SDG 12 & Responsible consumption and production & 4.54 & 0.605 & 0.000 & 4 \\
\hline SDG 10 & Reduced inequalities & 2.90 & 1.018 & 0.000 & 14 \\
\hline SDG 7 & Affordable and clean energy & 3.84 & 0.606 & 0.000 & 8 \\
\hline SDG 6 & Clean water and sanitation & 4.55 & 0.635 & 0.000 & 3 \\
\hline SDG 13 & Climate action & 4.56 & 0.570 & 0.000 & 2 \\
\hline SDG 14 & Life below water & 2.84 & 0.889 & 0.000 & 15 \\
\hline SDG 8 & Decent work and economic growth & 4.47 & 0.694 & 0.000 & 6 \\
\hline SDG 16 & Peace, justice and strong institution & 2.87 & 0.797 & 0.000 & 16 \\
\hline SDG 17 & Partnership for goals & 3.04 & 0.990 & 0.000 & 12 \\
\hline
\end{tabular}

Table 4. Summary analysis of the 10 SDGs highly impacted by the construction industry.

\begin{tabular}{|c|c|c|c|c|c|c|}
\hline & & \multicolumn{5}{|c|}{ Test Value 3.5} \\
\hline CODE & Goals & Mean & Standard Deviation & Sig Two-Tailed & Rank & Statically Significant \\
\hline SDG 15 & Life on land (biodiversity) & 4.32 & 0.814 & 0.000 & 7 & Yes \\
\hline SDG 5 & Gender equality & 3.70 & 0.950 & 0.029 & 10 & Yes \\
\hline SDG 11 & Sustainable cities and communities & 4.67 & 0.583 & 0.000 & 1 & Yes \\
\hline SDG 3 & Good health and well-being & 3.79 & 0.817 & 0.000 & 9 & Yes \\
\hline SDG 9 & Industry, innovation and infrastructure & 4.52 & 0.622 & 0.000 & 5 & Yes \\
\hline SDG 12 & Responsible consumption and production & 4.54 & 0.605 & 0.000 & 4 & Yes \\
\hline SDG 7 & Affordable and clean energy & 3.84 & 0.606 & 0.000 & 8 & Yes \\
\hline SDG 6 & Clean water and sanitation & 4.55 & 0.635 & 0.000 & 3 & Yes \\
\hline SDG 13 & Climate action & 4.56 & 0.570 & 0.000 & 2 & Yes \\
\hline SDG 8 & Decent work and economic growth & 4.47 & 0.694 & 0.000 & 6 & Yes \\
\hline Kendall's W & - & - & - & - & - & 0.218 \\
\hline Chi-Square & - & - & - & - & - & 205.865 \\
\hline Df & - & - & - & - & - & 9 \\
\hline \multirow[t]{2}{*}{ Asymp Sig } & - & - & - & - & - & 0.000 \\
\hline & & \multicolumn{5}{|c|}{ Test Value 3.5} \\
\hline CODE & Goals & Mean & Standard Deviation & Sig Two-Tailed & Rank & Statically Significant \\
\hline SDG 15 & Life on land (biodiversity) & 4.32 & 0.814 & 0.000 & 7 & Yes \\
\hline SDG 5 & Gender equality & 3.70 & 0.950 & 0.029 & 10 & Yes \\
\hline SDG 11 & Sustainable cities and communities & 4.67 & 0.583 & 0.000 & 1 & Yes \\
\hline SDG 3 & Good health and well-being & 3.79 & 0.817 & 0.000 & 9 & Yes \\
\hline SDG 9 & Industry, innovation and infrastructure & 4.52 & 0.622 & 0.000 & 5 & Yes \\
\hline SDG 12 & Responsible consumption and production & 4.54 & 0.605 & 0.000 & 4 & Yes \\
\hline SDG 7 & Affordable and clean energy & 3.84 & 0.606 & 0.000 & 8 & Yes \\
\hline SDG 6 & Clean water and sanitation & 4.55 & 0.635 & 0.000 & 3 & Yes \\
\hline SDG 13 & Climate action & 4.56 & 0.570 & 0.000 & 2 & Yes \\
\hline SDG 8 & Decent work and economic growth & 4.47 & 0.694 & 0.000 & 6 & Yes \\
\hline Kendall's W & $-\quad-2000$ & - & - & - & - & 0.218 \\
\hline Chi-Square & - & - & - & - & - & 205.865 \\
\hline Df & - & - & - & - & - & 9 \\
\hline Asymp Sig & - & - & - & - & - & 0.000 \\
\hline
\end{tabular}


According to Siegal and Castellan [65], for Kendall's W, "no agreement" and "complete agreement" are represented by the values 0 and +1 , respectively, from a range 0 to +1 . For this study, the value of Kendall's W for ranking the 10 SDGs by the different professionals was 0.218 , indicating a degree of less agreement amongst the rankings and statistically significant at the 0.000 level. Siegel and Castellan [65] further suggested that, where the number of assessed factors is more than seven and the sample size is more than twenty, the Chi-square value instead of Kendall's W value must be used. After the survey among 130 respondents (with 103 received), the data analysis revealed 10 critical SDGs to be highly impacted by the construction industry. With a response rate of 103 and 10 SDGs considered critical, it became necessary to use the Chi-square value instead of Kendall's W value based on Siegel and Castellan's recommendation [65]. Under the degree of freedom of 9 (based on the 10 critical SDGs), the Chi-square value calculated was 205.865, with a probability of occurrence under $p<0.001$ (i.e., Asymp. Sig $=0.000$ ).

This result implies that though the respondents cut across different professional disciplines, they showed a significant degree of agreement regarding the various SDGs' ranking as impacted by the construction industry.

\subsubsection{Sustainable Cities and Communities (SDG 11)}

SDG 11 seeks to make cities and human settlements inclusive, safe, resilient and sustainable. It provides an unparalleled opportunity to attain collective and inclusive progress and achieve sustainable development in the world. With a mean score (MS) $=4.67$ and a standard deviation $(\mathrm{SD})=0.583$, this goal was ranked as first by the respondents of this study. This means that the construction industry sees itself playing a pivotal role in achieving this goal by inclusively making cities and human settlements safe, resilient and sustainable. This finding concurs with that reported in other studies $[35,66,67]$.

SDG 11 is a critical goal because inadequate housing negatively impacts urban equity and inclusion, safety and livelihood opportunities, and negative health conditions [68]. According to the United Nations Global Compass (UNGC) [69], close to 70\% of the world's population will live in cities by 2050 . This makes cities critical in achieving a sustainable future for the world [69]. Since the construction industry plays a vital role in developing cities, key stakeholders need to plan how such cities and communities could be appropriately created. In the quest to conduct this, the UNGC [69] (p. 1) lists certain critical areas needed to achieve the desired progress on SDG 11 to include "identifying and agreeing on the most sustainable ways (activities that need to be ceased and accelerated respectively) to achieve the target; building capacities and skills across various stakeholder groups to deliver; securing finance, innovative designs and delivery models and projects for integrated city infrastructure; and ensuring the practical processes for multi-stakeholder engagement in all stages of urban development that build consensus, inclusion, resilience, and sustainability".

In seeking the views of some interviewees concerning the role of the construction industry in achieving SDG 11, this is what some had to say:

"The construction industry contributes to the development of communities that offer sustainable and affordable housing provision for the people on low income and the poor"-Interviewee 'G'.

It was acknowledged that the construction industry is crucial in developing sustainable cities and communities by delivering a sustainable built environment. Hence, Interviewee 'A' describes the use of, "Pocket homes as a concept that may help get people on the property market-progression is needed to continue from this to larger schemes/family options".

However, Interviewee ' $\mathrm{P}$ ' recommends that, "Building smart cities and communities that are resilience and can adapt to changes or the development of greener spaces especially in developing countries will be of benefit". 


\subsubsection{Climate Action (SDG 13)}

Climate change is seen to be a critical SDG because it can undermine the remaining 16 SDGs. However, it tends to reinforce all the 17 SDGs [70]. SDG 13 focuses on the need to adopt urgent measures to stop climate change. This SDG was ranked as second (MS $=4.56$, $\mathrm{SD}=0.570$ ), an indication of the construction industry's seriousness towards achieving it (see Tables 3 and 4). Other related studies have identified this SDG $[35,66,67]$ as important, especially as the construction industry worldwide seek ways to reduce their impacts on the environment.

Like other sectors, the construction industry is noted for its contribution to the greenhouse gas emissions [71]. This notwithstanding, there have been numerous efforts put in place by various sectors to control such emissions. According to the UNGC [72], companies can achieve this SDG by decarbonizing their operations and supply chains by continuously improving energy efficiency, reducing the carbon footprints of their products, services and processes, and setting ambitious emissions reduction targets in line with climate science. The construction industry consumes many natural resources and produces a large amount of waste from its operations. Goal 13 is about taking urgent climate action to combat climate change and its impacts on society; this goal is supported by five targets and measured through eight indicators. Achieving quality and a sustainable built environment can contribute to the realisation of the SDGs by implementing relevant environmental protection strategies during urban development [73]. When asked how the construction industry could contribute its quota to achieving this goal, two of the interviewees indicated as follows:

"The construction industry should develop and implement strategies that will address the impact of climate change. Improve climate change education and awareness and the monitoring of the impacts of climate change on construction"-Interviewee ' $\mathrm{J}$ '.

"Encouraging government to implement Agenda 21 for the developing countries and the education of people to accept low energy building materials"-Interviewee 'B'.

\subsubsection{Clean Water and Sanitation (SDG 6)}

The provision of clean water and sanitation is considered in SDG 6; the goal consisting of eight targets and eleven indicators ensure availability and sustainable management of water and sanitation for all by 2030. This goal was ranked as the third by the respondents (MS $=4.55, \mathrm{SD}=0.635)$, an indication that the construction industry has at heart to protect water bodies (see Tables 3 and 4). This finding corroborates with that reported in the literature (see $[35,66,67])$.

Access to water and sanitation are basic human rights and are critical sustainable development challenges [74]. These challenges may worsen when competing demands for clean, fresh water are exacerbated by climate change, putting pressure on water quality and availability [74]. This means that the construction sector has a key role in minimising its impact on the climate to protect water bodies. In addition to businesses finding ways to minimise their impacts on the climate, there is also the need for certain measures to be put in place by various sectors to alleviate some of these challenges. When asked about some of the measures which the construction industry can put in place to ensure clean water and sanitation, the interviewees had this to say:

"The industry could support the constructing of facilities for clean water and good sanitation"-Interviewee ' $\mathrm{P}$ '.

"Construction organisations must take the necessary steps to protect freshwater bodies close to construction sites from possible contamination. The design of smart, innovative and sustainable buildings that offer improvement in water use could contribute to the attainment of this $S D G$ "-Interviewee ' $A$ '. 


\subsubsection{Responsible Consumption and Production (SDG 12)}

SDG 12-responsible consumption and production-was ranked fourth by the respondents with an MS $=4.54$ and SD $=0.605$ (see Tables 3 and 4). This SDG focuses on decoupling economic growth from resource use and environmental degradation without any detrimental effects on people. This goal is viewed as a standalone and includes eight specific targets plus three targets related to means of implementation [75]. The construction industry generates a huge burden on the environment and society, with the current consumption patterns and production systems heavily relying on traditional practices and older technologies [76]. These technologies are highly inefficient, generate huge amounts of waste and consume high energy levels [76]. The problems tend to cause various environmental issues such as environmental pollution, greenhouse gas emissions and excessive consumption of resources [77]. Therefore, there is the need for the construction industry to implement sustainable consumption and production (SCP) strategies. This can be performed through the efficient use of natural resources and waste reduction from construction sites by recycling and reusing building materials. This will contribute to efforts toward the realisation of SDG 12, targets 12.2 and 12.5. One of the interviewees suggested the following SCP as key in doing so:

"Making recycling mandatory for construction and the reuse of waste from other industries such as the Agriculture sector for construction purposes can substantially help"-Interviewee 'C'.

\subsubsection{Industry, Innovation and Infrastructure (SDG 9)}

Goal 9 of the Sustainable Development Goals is about industry, innovation and infrastructure. SDG 9 is supported by eight targets and twelve indicators to build resilient infrastructure, promote inclusive and sustainable industrialisation and foster innovation. The respondents ranked this as the fifth goal (MS $=4.52, \mathrm{SD}=0.622$ ) in its quest to achieve the SDGs (see Tables 3 and 4). The construction industry has a key role in building resilient infrastructure, promoting inclusive and sustainable industrialisation and fostering innovation. The construction industry's contribution to achieving this goal is well reported in the literature $[35,66,67]$. When asked how the construction industry could achieve this goal, one of the interviewees indicated that:

"The construction industry should lead the Sustainable retrofitting of buildings/assets and the refurbishment and maintenance of old buildings"-Interviewee ' $\mathrm{O}$ '.

The industry should develop and align its strategies with the SDGs both at organisational and projects levels. This could ensure that the project delivered (new build or refurbishment) demonstrate sustainable development.

\subsubsection{Decent Work and Economic Growth (SDG 8)}

Sustainable Development Goal 8 (SDG 8) was ranked sixth by the respondents with an MS $=4.47$ and SD $=0.694$ (see Tables 3 and 4 ). This SDG seeks to promote decent work and economic growth through sustained, inclusive and sustainable economic growth, full and productive employment and decent work for all by 2030. This is captured in SDG 8, which is supported by 12 targets and underpinned by 16 indicators. This goal supports the mutual relationship between economic, social and environmental policies, full employment as well as decent work [68]. It is an established fact that globally, labour productivity has increased with unemployment back to the pre-financial level [68]. All industries, therefore, have roles to play in ensuring the provision of decent work, especially, to the upcoming younger generation. Since the global economy is growing at a slower pace with the productivity widening, especially, between the lower- and middle-income countries, the construction industry must sit up. Since this industry has been established as the backbone of every economy, the respondents were asked about the role the industry could play in ensuring that it achieves SDG 8. One of the responses obtained from the interviewees was as follows: 
"The construction industry can provide a productive and decent workforce for all by developing an adaptive workforce that can have different skills" - Interviewee ' $\mathrm{B}$ '.

The provision of employment and decent work for all promotes sustainable economic growth which is at the heart of the 2030 agenda for sustainable development. Promoting sustainable procurement practices that protect employees' labour rights, modern slavery and the prevention of child labour on construction sites should be implemented across the whole supply chain especially when dealing with sub-contractors. In the view of Interviewee ' $\mathrm{H}^{\prime}$, the construction industry can "Drive economic growth through constructionrelated employment; make construction work decent, clean, safe and easy to build". According to Goubran [35], the construction industry has a major role in ensuring that this goal is achieved through the provision of a safe working environment and implementing sustainable construction practices, which provide new opportunities to create financial empowerment.

\subsubsection{Life on Land (Biodiversity) (SDG 15)}

Terrestrial ecosystems have the tendency to provide a series of goods, raw materials for construction and energy, among other things. Hence, preserving diverse forms of life on land requires targeted efforts to protect, restore and promote the conservation and sustainable use of the ecosystem. Sustainable Development Goal 15 was ranked as the seventh $(\mathrm{MS}=4.32, \mathrm{SD}=0.814$ ) by the respondents (see Tables 3 and 4). SDG 15 (biodiversity) is supported by 12 targets and underpinned by 14 indicators aimed at protecting, restoring and promoting the sustainable use of terrestrial ecosystems and the sustainable management of forests to combat desertification and halt or reverse land degradation and halt biodiversity loss by 2030. The construction industry impacts negatively on biodiversity, and Opoku [45] argues that the industry should conserve and preserve biodiversity which is crucial for the realisation of the SDGs during the delivery of projects. Urban mining can be one of the strategies used to ensure the achievement of SDG 15 by mining for metals produced from electronic waste generated as a result of construction works instead of mining for these minerals or metals from rocks which destroys the environment [78]. On exploring the roles which the construction industry could play to preserve biodiversity, some of the interviewees had this to say:

"Providing infrastructure in areas of land degradation to help halt desertification or the provision of new/alternative habitats for certain species of animals could help address the problem of biodiversity" - Interviewee ' $\mathrm{L}$ '.

"Reducing deforestation by promoting more responsible sourcing of timber materials that are Forest Stewardship Council (FSC) certified and industry awareness of environmental calendar about when certain species are vulnerable is a useful strategy" - Interviewee ' $\mathrm{C}$ '.

\subsubsection{Affordable and Clean Energy (SDG 7)}

The provision of affordable and clean energy is presented in SDG 7 to ensure access to affordable, reliable, sustainable and modern energy for all. In the view of the respondents, the construction industry has a key role to play in ensuring that this SDG is achieved. SDG 7 was ranked eighth by the respondents with an MS $=3.84$ and SD $=0.606$ (see Tables 3 and 4). SDG 7 is achieved through five targets and six measurable indicators. Electricity usage on construction sites is one way the industry can contribute to SDG 7; the construction industry could make it a policy to source electricity for all temporary construction processes and operations from renewable energy sources. Another initiative the industry is using to help achieve this goal is the provision of net-zero energy buildings or energy-efficient buildings which come with a greater reduced energy cost [79]. When asked how the construction industry can help in achieving this goal, one of the interviewees had this to say:

"Efficient use of energy in buildings is important and the provision of smart energy solutions that are user friendly and easily understood by the end-users"-Interviewee ' $F$ '. 


\subsubsection{Good Health and Well-being (SDG 3)}

Construction workers are hundred times more likely to die from various diseases as a result of their jobs. Traditionally, this industry is classified as having a rough and tumble work environment. As a matter of fact, the well-being of employees is of much importance to the industry. In seeking the views of the respondents regarding the role the construction industry plays in achieving the SDGs, the role of the industry in achieving SDG 3 was ranked nine out of the ten significant SDGs. SDG 3 obtained an $\mathrm{MS}=3.79$ and $\mathrm{SD}=0.817$. SDG 3 is on good health and well-being and consists of 13 targets and 28 indicators aimed at ensuring healthy lives and promoting well-being for all at all ages. The construction industry is known to be labour intensive with poor working conditions in most cases; however, the industry can contribute to good health and well-being (SDG 3) by promoting a good work-life balance through job share and flexible working arrangements. When asked how the construction industry could play its role in achieving SDG 3, an interviewee had the following to say:

"Construction sustainable building types to promote wellbeing; right working environment to reduced danger of construction site, improve health and safety awareness and the occupational health of workers" - Interviewee ' $\mathrm{J}$ '.

The creation of green spaces in the built environment as part of planning policies help to purify the air from pollutants, and access to such green areas offers psychological benefits including improved mental health [80]. One measure the construction industry is using to improve the quality of life and human health is the implementation of sustainable construction practices in the construction process [79].

\subsubsection{Gender Equality (SDG 5)}

SDG 5 aims to end every form of discrimination against women and girls. This includes an end to violence and other forms of harmful practices, and the full participation of women in leadership positions. This SDG does not only depict a fundamental human right but also ensures that women are fully represented in all sectors of the economy. SDG 5 is made up of nine targets and fourteen indicators and aims at achieving gender equality and empowering all women and girls by 2030. In exploring the role of the construction industry in achieving the SDGs, respondents ranked this SDG as the tenth with an MS $=3.70$ and SD $=0.950$ (see Tables 3 and 4). Generally, women are disadvantaged in their career journeys due to a gender bias in construction organisations; this affects women's career progression into leadership positions in the construction sector [49]. The promotion of gender equality in the construction industry is essential in attracting and retaining talents that can improve productivity in the industry. The construction industry can help achieve gender equality by creating awareness and also by ending stereotypes about the industry being a masculine one to encourage more women to join the industry [81]. When asked how the construction industry could achieve this SDG, the interviewees suggested the following:

"The construction industry must make it easy to recruit, retain and support women taking a career in the industry"-Interviewee ' $\mathrm{C}$ '.

"The construction industry can help by improving the image and making it easy to attract the underrepresented groups in the industry such as women and Black, Asian and Minority Ethnic (BAME) groups"-Interviewee 'D'.

\section{Conclusions}

The SDGs represent a new direction for the global community, integrating social, economic and environmental sustainability into all policies and strategies to eliminate poverty and inequality to achieve a more prosperous society. Though the construction industry's activities impact negatively on the environment, the industry can act as a driver towards the realisation of the SDGs. The SDGs provide the construction industry with a new lens through which global needs and desires can be translated into business solutions. 
This study explored the role of the construction industry in achieving the 2030 Sustainable Development Goals.

The paper adopted a mixed-method approach using exploratory sequential and qualitative data to augment the study's quantitative outcome. This design involved two stages, i.e., an initial quantitative instrument phase, followed by a qualitative data collection phase. A questionnaire was prepared and administered among professionals in the quantitative phase, both within industry and academia. Data from the quantitative phase were analysed via descriptive and inferential statistics. The data obtained from the questionnaire survey were later validated through 16 semi-structured interviews with sustainable construction experts. The findings show that the construction industry has a critical role in achieving almost all 17 SDGs. The roles were, however, prevalent in 10 key SDGs, namely: sustainable cities and communities (SDG 11); climate action (SDG 13); clean water and sanitation (SDG 6); responsible consumption and production (SDG 12); industry, innovation and infrastructure (SDG 9); life on land (Biodiversity) (SDG 15); gender equality (SDG 5); good health and well-being (SDG 3); affordable and clean energy (SDG 7); decent work and economic growth (SDG 8). The interviewees agreed to and confirmed the role played by the construction industry in achieving these SDGs to realise the SDGs by 2030. The interview further revealed that the construction industry should engage with construction businesses to align business strategies with the SDGs. The construction industry should collaborate with government agencies, industry peers and policymakers to integrate the SDGs into long-term business strategies and work towards realising the world we want.

The construction industry is a key partner in the global effort to achieve the Sustainable Development Goals by developing sustainable infrastructural projects, especially in developing countries. The SDGs' achievement will require new investments in sustainable infrastructure globally, especially in the Global South. The construction industry provides employment opportunities for unemployed people in communities where building projects are undertaken to eradicate poverty and improve people's standard of living. Governments across the globe should use the construction industry as drivers in developing the right policies and regulations. Construction organisations should collaborate with government agencies, industry peers and policymakers to integrate the SDGs into long-term business strategies and work towards realising the world we want. While the construction industry can contribute to the realisation of all the SDGs, this study identifies the top 10 SDGs that the industry can have the maximum impact on in the 2030 sustainable agenda. A key limitation associated with this study is the small sample size that was used to obtain the data. Future studies could be expanded to obtain the views of the wider population to enable better generalisation of the findings.

Author Contributions: Conceptualization, A.O. and W.F.; methodology, A.O., K.A. and J.A.O.; validation, A.O. and K.A.; formal analysis, A.O. and J.A.O.; investigation, A.O. and W.F.; resources, A.O. and C.C.; data curation, A.O. and K.L.L.; writing-original draft preparation, A.O. and K.A.; writingreview and editing, A.O., V.A. and C.C.; visualization, K.L.L. and W.F.; project administration, A.O. All authors have read and agreed to the published version of the manuscript.

Funding: This research received no external funding.

Institutional Review Board Statement: Not applicable.

Informed Consent Statement: Not applicable.

Conflicts of Interest: The authors declare no conflict of interest.

\section{References}

1. United Nations. Transforming Our World: The 2030 Agenda for Sustainable Development, Resolution Adopted by the General Assembly. Seventieth Session on 25 September 2015. A/RES/70/1. 2015. Available online: https://www.un.org/ga/search/ view_doc.asp?symbol=A/RES/70/1\&Lang=E (accessed on 10 October 2020).

2. Corporate Citizenship. Advancing the Sustainable Development Goals: Business Action and Millennials' Views; Corporate Citizenship: London, UK, 2016. 
3. SDSN. Getting Started with the SDGs in Cities: A Guide for Stakeholders; U.N. Sustainable Development Solutions Network (SDSN): New York, NY, USA, 2016.

4. UKSSD. Measuring Up: How the U.K. Is Performing on the U.N. Sustainable Development Goals; U.K. Stakeholders for Sustainable Development (UKSSD): London, UK, 2018.

5. Adams, A.C. The Sustainable Development Goals, Integrated Thinking and the Integrated Report; International Integrated Reporting Council (IIRC): London, UK, 2017.

6. Pizzi, S.; Caputo, A.; Corvino, A.; Venturelli, S. Management research and the U.N. sustainable development goals (SDGs): A bibliometric investigation and systematic review. J. Clean. Prod. 2020, 276, 124033. [CrossRef]

7. Robinson, J. Squaring the circle? Some thoughts on the idea of sustainable development. Ecol. Econ. 2004, 48, 369-384. [CrossRef]

8. Sachs, D.J.; Schmidt-Traub, G.; Mazzucato, M.; Messner, D.; Nakicenovic, N.; Rockström, J. Six Transformations to achieve the Sustainable Development Goals. Nat. Sustain. 2019, 2, 805-814. [CrossRef]

9. Dickens, C.; McCartney, M.; Tickner, D.; Harrison, I.J.; Pacheco, P.; Ndhlovu, B. Evaluating the Global State of Ecosystems and Natural Resources: Within and Beyond the SDGs. Sustainability 2020, 12, 7381. [CrossRef]

10. Hopwood, B.; Mary Mellor, M.; O’Brien, G. Sustainable Development: Mapping Different Approaches. Sustain. Dev. 2005, 13, 38-52. [CrossRef]

11. Waage, J.; Yap, C.; Bell, S.; Levy, C.; Mace, G.; Pegram, T.; Unterhalter, E.; Dasandi, N.; Hudson, D.; Kock, R.; et al. Governing the U.N. sustainable development goals: Interactions, infrastructures, and institutions. Lancet Glob. Health 2015, 3, e251-e252. [CrossRef]

12. Nilsson, M.; Griggs, D.; Visbeck, M. Map the interactions between Sustainable Development Goals. Nature 2016, 534, 320-322. [CrossRef]

13. Bhaduri, A.; Bogardi, J.; Siddiqi, A.; Voigt, H.; Vörösmarty, C.; Pahl-Wostl, C.; Bunn, S.E.; Shrivastava, P.; Lawford, R.; Foster, S.; et al. Achieving Sustainable Development Goals from a Water Perspective. Front. Environ. Sci. 2016, 4, 64. [CrossRef]

14. Allen, C.; Metternicht, G.; Wiedmann, T. Prioritising SDG targets: Assessing baselines, gaps and interlinkages. Sustain. Sci. 2019, 14, 421-438. [CrossRef]

15. CISL. Towards a Sustainable Economy: The Commercial Imperative for Business to Deliver the U.N. Sustainable Development Goals; University of Cambridge Institute for Sustainability Leadership (CISL): Cambridge, UK, 2017.

16. UNSC. Interlinkages of the 2030 Agenda for Sustainable Development, Prepared by the Interlinkages Working Group of the InterAgency and Expert Group on Sustainable Development Goal Indicators (IAEG-SDGs) United Nations Statistical Commission (UNSC). 2019. Available online: https:/ / unstats.un.org/unsd/statcom/50th-session/documents/BG-Item3a-Interlinkages-2030 -Agenda-for-Sustainable-Development-E.pdf (accessed on 16 January 2021).

17. Kroll, C.; Warchold, A.; Pradhan, P. Sustainable Development Goals (SDGs): Are we successful in turning trade-offs into synergies? Palgrave Commun. 2019, 5, 140. [CrossRef]

18. International Council for Science (ICS). A Guide to SDG Interactions: From Science to Implementation; International Council for Science: Paris, France, 2017.

19. Griggs, D.; Stafford-Smith, M.; Gaffney, O.; Rockstrom, J.; Öhman, M.C.; Shyamsundar, P.; Steffen, W.; Glaser, G.G.; Kanie, N.; Noble, I. Sustainable development goals for people and planet. Nature 2013, 495, 305-307. [CrossRef] [PubMed]

20. Holm, F.H. Towards a Sustainable Built Environment Prepared for Climate Change? A Paper Presented at the Global Policy Summit on the Role of Performance-Based Building Regulations in Addressing Societal Expectations, International Policy, and Local Needs. 3-5 November 2003; National Academy of Sciences: Washington, DC, USA, 2003.

21. Postalcı, İ.E.; Atay, G.F. Rethinking on Cultural Sustainability in Architecture: Projects of Behruz Çinici. Sustainability 2019, 11, 1069. [CrossRef]

22. OECD. OECD Environmental Outlook to 2030; OECD Publishing (Organisation for Economic Co-Operation and Development): Paris, France, 2008; ISBN 978-92-64-04048-9.

23. Grierson, D. Towards a sustainable built environment. CIC Start Online Innov. Rev. 2009, 1, 70-77.

24. Lewis, J.O. Renovate or Demolish/Rebuild: What are the Drivers? EuroACE, Brussels, Renovate Europe Day, 11 October 2012. Available online: http://www.renovateeurope.eu/uploads/REDay2012\%20ppts/REDay2012_Workshop_Owen_Lewis.pdf (accessed on 15 September 2019).

25. Wilson, A. Sustainable Development Goal 11: Make Cities Safe and Sustainable. 2015. Available online: https://www. greenbiz.com/article/sustainable-development-goal-11-make-cities-and-human-settlements-inclusive-safe-and (accessed on 25 December 2019).

26. United Nations. Transforming Our World: The 2030 Agenda for Sustainable Development, A/RES/70/1; Preparatory Committee for the United Nations Conference on Sustainable Development; First Session, 17-19 May 2010; United Nations General Assembly: New York, NY, USA, 2010.

27. Evans, J.; Jones, P. Rethinking Sustainable Urban Regeneration: Ambiguity, Creativity, and the Shared Territory. Environ. Plan. A Econ. Space 2008, 40, 1416-1434. [CrossRef]

28. UNDESA. The Sustainable Development Goals Report 2019, Department of Economic and Social Affairs (DESA); United Nations Publications: New York, NY, USA, 2019. 
29. Teferi, Z.A.; Newman, P. Slum Upgrading: Can the $1.5^{\circ} \mathrm{C}$ Carbon Reduction Work with SDGs in these Settlements? Urban Planning, 3, 52-56 UN, Sustainable Cities and Human Settlements, United Nations Sustainable Development Knowledge Platform. 2018. Available online: https:/ / sustainabledevelopment.un.org/topics/sustainablecities (accessed on 2 October 2020).

30. Boyle, J.; Cunningham, M.; Dekens, J. Climate Change Adaptation and Canadian Infrastructures; International Institute for Sustainable Development (IISD): Winnipeg, MB, Canada, 2013.

31. House of Lords. Select Committee on National Policy for the Built Environment: Building Better Places; Report of Session 2015-2016; The Stationery Office: London, UK, 2016; Available online: http:/ /www.publications.parliament.uk/pa/ld201516/ldselect/ ldbuilt/100/10002.htm (accessed on 10 April 2019).

32. Opoku, A. SDG2030: A sustainable built environment's role in achieving the post-2015 United Nations Sustainable Development Goals. In Proceedings of the 32nd Annual ARCOM Conference 2016, Manchester, UK, 5-7 September 2016; Chan, P.W., Neilson, C.J., Eds.; Association of Researchers in Construction Management: Manchester, UK, 2016; Volume 2, pp. $1149-1158$.

33. Broo, D.G.; Lamb, K.; Ehwi, R.J.; Parn, E.; Koronaki, A.; Makri, C.; Zomer, T. Built environment of Britain in 2040: Scenarios and strategies. Sustain. Cities Soc. 2021, 65, 102645. [CrossRef]

34. Wright, H.; Dimsdale, T.; Healy, C.; Orozco, D.; Williamson, S.; Mabey, N. Sustainable Infrastructure and the Multilateral Development Banks: Changing the Narrative, Briefing Paper; Third Generation Environmentalism Ltd. (E3G): London, UK, 2018.

35. Goubran, S. On the Role of Construction in Achieving the SDGs. J. Sustain. Res. 2019, 1, e190020. [CrossRef]

36. Silvius, G. Sustainability as a new school of thought in project management. J. Clean. Prod. 2017, 166, 1479-1493. [CrossRef]

37. BDG. Build a Better Future with the Sustainable Development Goals: A Practical Guide for Construction and Property Companies; Bioregional Development Group (BDG): Oxford, UK, 2019.

38. Alawneh, R.; Ghazali, F.; Ali, H.; Sadullah, A.F. A Novel framework for integrating United Nations Sustainable Development Goals into sustainable non-residential building assessment and management in Jordan. Sustain. Cities Soc. 2019, 49, 101612. [CrossRef]

39. Gálvez-Martos, J.-L.; Styles, D.D.; Schoenberger, H.; Zeschmar-Lahl, D. Construction and demolition waste best management practice in Europe. Resour. Conserv. Recycl. 2018, 136, 166-178. [CrossRef]

40. Mahpour, A. Prioritizing barriers to adopt a circular economy in construction and demolition waste management. Resour. Conserv. Recycl. 2018, 134, 216-227. [CrossRef]

41. Ofori, G. Construction in developing countries: Current imperatives and potential. In Proceedings of the CIB World Building Congress 2016, Tampere, Finland, 30 May-3 June 2016; Kähkönen, K., Keinänen, M., Eds.; Department of Civil Engineering, Construction Management and Economics, Tampere University of Technology: Tampere, Finland, 2016; Volume 1, pp. 39-52.

42. RICS; UNGC. Advancing Responsible Business in Land, Construction and Real Estate Use and Investmen-Making the Sustainable Development Goals a Reality; United Nations Global Compact (UNGC): London, UK, 2018.

43. Gareis, R.; Huemann, M.; Martinuzzi, A. Project Management and Sustainable Development Principles; Project Management Institute Inc.: Pennsylvania, PA, USA, 2013.

44. Gareis, R.; Heumann, M.; Martinuzzi, A. Relating sustainable development and project management: A conceptual model. In Proceedings of the PMI Research and Education Conference; Project Management Institute: Washington, DC, USA, 2010.

45. Opoku, A. Biodiversity and the Built Environment: Implications for the Sustainable Development Goals (SDGs). Resour. Conserv. Recycl. 2019, 141, 1-7. [CrossRef]

46. Lepczyk, C.A.; Aronson, M.F.J.; Evans, K.L.; Goddard, M.A.; Lerman, S.B.; MacIvor, J.S. Biodiversity in the City: Fundamental Questions for Understanding the Ecology of Urban Green Spaces for Biodiversity Conservation. BioScience 2017, 67, 799-807. [CrossRef]

47. SIDA. Urban Development: Biodiversity and Ecosystems; Swedish International Development Cooperation Agency (SIDA): Stockholm, Sweden, 2016.

48. Omer, M.A.B.; Noguchi, T. A conceptual framework for understanding the contribution of building materials in the achievement of Sustainable Development Goals (SDGs). Sustain. Cities Soc. 2020, 52, 101869. [CrossRef]

49. Opoku, A.; Williams, N. Second-generation gender bias: An exploratory study of the women's leadership gap in a U.K. construction organisation. Int. J. Ethics Syst. 2019, 35, 2-23. [CrossRef]

50. Wu, H.; Zuo, J.; Zillante, G.; Wang, J.; Yuan, H. Status quo and future directions of construction and demolition waste research: A critical review. J. Clean. Prod. 2019, 240, 118163. [CrossRef]

51. Jain, S.; Singhal, S.; Kumar, J.N.; Bhaskar, K. Construction and demolition waste recycling: Investigating the role of theory of planned behaviour, institutional pressures and environmental consciousness. J. Clean. Prod. 2020, 263, 121405. [CrossRef]

52. Creswell, J.W. Steps in Conducting a Scholarly Mixed Methods Study: What I am Looking for Core Characteristics: Do You Have a Quantitative Database? (Closed-Ended); University of Nebraska-Lincoln: Lincoln, NE, USA, 2013.

53. Kroll, T.; Neri, M. Designs for Mixed Methods Research. Mix. Methods Res. Nurs. Health Sci. 2009, 31-49. [CrossRef]

54. Wisdom, J.; Creswell, J.W. Mixed Methods: Integrating Quantitative and Qualitative Data Collection and Analysis While Studying Patient-Centered Medical Home Models; U.S. Department of Health and Human Services: Rockville, MD, USA, 2013.

55. Chan, A.P.C.; Darko, A.; Ameyaw, E.E. Strategies for promoting green building technologies adoption in the construction industry-An international study. Sustainability 2017, 9, 969. [CrossRef]

56. Taherdoost, H. Sampling Methods in Research Methodology; How to Choose a Sampling Technique for Research. Int. J. Acad. Res. Manag. 2016, 5, 18-27. [CrossRef] 
57. Rowley, J. Designing and using research questionnaires. Manag. Res. Rev. 2014, 37, 308-330. [CrossRef]

58. Agyekum, K.; Adinyira, E.; Oppon, A.J. Factors limiting the adoption of hemp as an alternative sustainable material for green building delivery in Ghana. Int. J. Build. Pathol. Adapt. 2021. [CrossRef]

59. Onwuegbuzie, A.J.; Johnson, R.B. The validity issue in Mixed Research. Res. Sch. 2006, 13, 48-63.

60. Saunders, B.; Sim, J.; Kingstone, T.; Baker, S.; Waterfield, J.; Bartlam, B.; Burroughs, H.; Jinks, C. Saturation in qualitative research: Exploring its conceptualization and operationalization. Qual. Quant. 2018, 52, 1893-1907. [CrossRef]

61. Morse, J.M. Designing qualitative research. In Handbook of Qualitative Research, 2nd ed.; Denizin, N.K., Lincoln, Y.S., Eds.; Sage: Thousand Oaks, CA, USA, 1994; pp. 220-235.

62. Guest, G. How many interviews are enough? An experiment with data saturation and variability. Field Methods 2006, 18, 59-82. [CrossRef]

63. Santos, J.R.A. Cronbach's alpha: A tool for assessing the reliability of scales. J. Ext. 1999, 37, 1-5.

64. Norusis, M.J. IBM SPSS Statistics 19 Guide to Data Analysis; Addison Wesley: Boston, MA, USA, 2011.

65. Siegel, S.; Castellan, N.J. Nonparametric Statistics for the Behavioural Sciences, 2nd ed.; McGraw-Hill: New York, NY, USA, 1988.

66. Gade, A.N.; Opoku, A. Challenges for implementing the sustainable development goals in the Danish construction industry: Building owner's perespective. In Proceedings of the 36th Annual ARCOM Conference, Leeds, UK, 7-8 September 2020; Scott, L., Neilson, C.J., Eds.; Association of Researchers in Construction Management: Leeds, UK, 2020; pp. 615-624.

67. Wieser, A.A.; Scherz, M.; Maier, S.; Passer, A.; Kreiner, H. Implementation of sustainable development goals in construction industry-A systematic consideration of synergies and trade-offs. Earth Environ. Sci. 2019, 323, 012177.

68. High Level Political Forum on Sustainable Development, HLPFSD, 2018 Review of SDGs Implementation: SDG 11-Make Cities and Human Settlements Inclusive, Safe, Resilient and Sustainable. 2018. Available online: Sustainabledevelopment.un.org/hlpf/ 2018 (accessed on 7 March 2021).

69. United Nations Global Compact, UNGC, Make Cities and Human Settlements Inclusive, Safe, Resilient and Sustainable. 2016. Available online: https://sdgcompass.org/wp-content/uploads/2016/04/Goal_11.pdf (accessed on 7 March 2021).

70. Johnsson, F.; Karlsson, I.; Rootzén, J.; Ahlback, A.; Gustavsson, M. The framing of a sustainable development goals assessment in decarbonizing the construction industry-Avoiding greenwashing. Renew. Sustain. Energy Rev. 2020, 131, 110029. [CrossRef] [PubMed]

71. Agyekum, K.; Opoku, A.; Oppon, A.J.; Opoku, D.G.J. Obstacles to green building project financing: An empirical study in Ghana. Int. J. Constr. Manag. 2020, 1-9. [CrossRef]

72. United Nations Global Compact (UNGC). Take Urgent Action to Combat Climate Change and Its Impact. 2016. Available online: https://sdgcompass.org/wp-content/uploads/2016/04/Goal_13.pdf (accessed on 7 April 2021).

73. Fang, X.; Shi, X.; Gao, W. Measuring urban sustainability from the quality of the built environment and pressure on the natural environment in China: A case study of the Shandong Peninsula region. J. Clean. Prod. 2020, 289, 125145. [CrossRef]

74. United Nations Global Compact (UNGC). Ensure Availability and Sustainable Management of Water and Sanitation for All. 2016. Available online: https://sdgcompass.org/wp-content/uploads/2016/04/Goal_6.pdf (accessed on 8 April 2021).

75. Gasper, D.; Shah, A.; Tankha, S. The framing of sustainable consumption and production in SDG 12. Glob. Policy 2019, 10, 1013. [CrossRef]

76. Ma, L.; Wang, L.; Skibniewski, M.J.; Gajda, W. An eco-innovative framework development for sustainable consumption and production in the construction industry. Technol. Econ. Dev. Econ. 2019, 25, 774-801. [CrossRef]

77. Govindan, K. Sustainable consumption and production in the food supply chain: A conceptual framework. Int. J. Prod. Econ. 2018, 195, 419-431. [CrossRef]

78. Kumar, V.; Teo, E.A.L. Towards a more circular construction model: Conceptualizing an open-BIM based estimation framework for urban mining. In CIB World Congress Hong Kong, 17 to 21 June 2019; International Council for Research and Innovation in Building and Construction (CIB): Ottawa, ON, Canada, 2019.

79. Liu, Z.J.; Pypłacz, P.; Ermakova, M.; Konev, P. Sustainable construction as a competitive advantage. Sustainability 2020, $12,5946$. [CrossRef]

80. Lee, A.C.; Jordan, H.C.; Horsley, J. Value of urban green spaces in promoting healthy living and wellbeing: Prospects for planning. Risk Manag. Healthc. Policy 2015, 8, 131-137. [CrossRef] [PubMed]

81. Powell, A.; Dainty, A.; Bagilhole, B. Achieving gender equality in the construction professions: Lessons from the career decisions of women construction students in the UK. In Proceedings of the 26th Annual ARCOM Conference, Leeds, UK, 6-8 September 2010; Volume 6. 